\title{
Knowledge and awareness of sickle cell anemia among dental students in Riyadh Elm University
}

\begin{abstract}
Introduction: Sickle cell disease has pathological effects in dental tissues and the oral cavity. Basic knowledge of sickle cell anemia among dentists and dental students before any dental procedure is mandatory.

Aim: This study aimed to determine the knowledge of dental students related to Sickle Cell Anemia.

Results: Of the 422 dental students, over half of the participants did not ever treat patients with sickle cell anemia $57.7 \%(n=244)$ or ask the patient for some investigation $53.7 \%(\mathrm{n}=227)$ or gives prophylactic antibiotic before extraction $52.4 \%$ $(n=221)$. Approximately half $53.6 \%(n=226)$ of students have information about oral manifestations of SCA and reported bleeding $52.8 \%(\mathrm{n}=223)$ as a serious complication during dental procedures. The majority $75.1 \%(n=316)$ think that patient's physician should be consulted about the patient's myocardial status and most of the participants $57.8 \%(\mathrm{n}=245)$ think that preventive dental care is important.

Conclusions: The awareness of dental students toward the sickle cell anemia is a satisfactory level, but dental School should provide more courses and training about the policy of treat patient with SCA.
\end{abstract}

Volume 10 Issue $3-2019$

\author{
Asma Al Meslet,' Heba Al Hamedi, ${ }^{2}$ Hanan Al \\ Zhrani, ${ }^{2}$ Khayria Al Somaly, ${ }^{2}$ Anfal Al Doukhi ${ }^{2}$ \\ 'Department of Oral Maxillofacial Surgery and Diagnostic \\ Sciences, Riyadh Elm University, Saudi Arabia \\ ${ }^{2}$ Dental Interns, Riyadh Elm University, Saudi Arabia
}

Correspondence: Asma Al Meslet, Department of Oral Maxillofacial Surgery and Diagnostic Sciences, Riyadh Elm University, Saudi Arabia, Email Asma.Almeslet@riyadh.edu.sa

Received: May 30, 2019| Published: June 10, 2019

\section{Introduction}

Anemia is a condition defined as lack of red blood cell or hemoglobin which is carries oxygen from the lungs to the tissues. ${ }^{1}$ Sickle cell anemia is an inherited blood disorder (IBD) caused by a mutation of the hemoglobin gene that affects hemoglobin structure and morphologic in erythrocytes; resulting in the formation of abnormal, sickle-shaped red blood cells. ${ }^{2}$ In SCA there is reducing the flow of the blood and oxygen into the body organs and impedes blood flow through small capillaries will cause blockage of blood vessels (i.e., vaso-occlusion). ${ }^{3}$ Epidemiology of Sickle Cell Disease in the United States, about 72000 people and 2 million are carriers. ${ }^{4}$ In Africa, more than 200000 infants are born yearly with SCD. ${ }^{5}$ The Eastern Province of Saudi Arabia is known to have one of the highest prevalence rates of SCD worldwide. ${ }^{6,7}$

Sickle Cell Disease Diagnosis Via a blood test to checks hemoglobin S National Human Genome Research Institute, 2016; NHBLI, 2018, SCD are now identified via new born screening. If the infant screens positive for SCD, they are retested to confirm the diagnosis. Complication of SCD can be prevent by early diagnosis. ${ }^{8,9,10}$

Sickle cell disease affects every major body system and increases the risk of multiple complications (Anemia, Stroke, Pulmonary hypertension, Cardiomyopathy, Renal infarction Osteoporosis, Avascular necrosis Osteomyelitis, Splenic infarction, Retinopathy, Chronic leg ulcers, Anxiety, Depression, Sleep disturbances) and early death. ${ }^{3,11}$

The pathological effects of sickle cell disease also occur in dental tissues and the oral cavity. The most common oral manifestations of the sickle cell disease are mucosal pallor, yellow tissue coloration, disorders of enamel and dentin mineralization, delayed tooth eruption, radiographic abnormalities, malocclusion, osteomyelitis of the jaw, hypercementosis, pulp stones, and asymptomatic pulp necrosis, glossitis and gingival enlargement. ${ }^{12-15}$
As a dentists and dental students, basic knowledge of sickle cell anemia before any dental procedure is mandatory because some medication such as non steroidal anti-inflammatory drugs (example aspirin and ibuprofen) is contraindication, and other example of important to be aware of SCA that the dentist must prescribe antibiotics before dental procedures to avoid the risk of infections. ${ }^{16-18}$

Aims of the study: To analyze and evaluate the knowledge, attitudes and Awareness toward Sickle Cell Anemia Among Dental students in Riyadh Elm university, Riyadh City, Kingdom of Saudi Arabia.

\section{Materials and methods}

Ethical Approval: Study proposal was submitted to the research center of Riyadh Elm University and ethical approval (Institutional Review Board IRB) was obtained. The study was registered under the registration number: FUGRP/2018/188.

Study Method: Quantitative.

Study Design: A cross sectional paper based questionnaire survey and An online survey was developed using surveymonkey.com.

Study Population: Dental students in Riyadh Elm University Riyadh City, Kingdom of Saudi Arabia.

Sample Size: 422 carrying out by using online Raosoft sample size calculator.

Questionnaire: A structured, close-ended, and self-administered questionnaire.

Consist of 24 questions: three questions requesting the respondents' biographic and practice demographic information. Nine questions related to their general knowledge of sickle cell disease and twelve questions related to their dental knowledge of sickle cell disease.

Statistical Analysis: The information and data from the study entered into an electronic database (SPSS ${ }^{\circledR}$ for windows ${ }^{\circledR}$ V.20). 


\section{Results}

Of the 422 dental students, the majority were aged between 24-27 years $(\mathrm{n}=193,46.5 \%)$. almost the half $212(50.2 \%)$ were males and $210(49.8 \%)$ were females. One hundred six $(25.0 \%)$ were in Level 12 followed by $79(18.6 \%)$ in level 11 and $74(17.5 \%)$ Is dental intern (Table 1).

Table I Demographic characteristics

\begin{tabular}{llll}
\hline & & Frequency & Percent \\
& & $(\mathrm{n})$ & $(\%)$ \\
\hline Age & 19-23 years & 152 & 36.6 \\
& $24-27$ years & 193 & 46.5 \\
Lender & Male & 70 & 16.9 \\
& Female & 212 & 50.2 \\
& Level 8 & 51 & 49.8 \\
& level 9 & 50 & 12 \\
& Level I0 & 64 & 11.8 \\
& Level II & 79 & 15.1 \\
& Level I2 & 106 & 18.6 \\
& Intern & 74 & 25 \\
\hline
\end{tabular}

Table 2 shows participants general knowledge of the sickle cell disease. Over the half of the participants $55.9 \%(\mathrm{n}=237)$ reported that results in anemia make SCD serious disease, $55.0 \%(\mathrm{n}=233)$ reported that newborn screening programs is the appropriate time to test for SCD, the majority of student think that the role of hemoglobin is to transport oxygen $63.6 \%(\mathrm{n}=269)$ and the early morning is the protocol to treat patients with SCA $55.0 \%(n=231)$.
Although 53.6\% ( $\mathrm{n}=226)$ knew the effective method to reduces the risk of SCD, but only $44.6 \%(n=186)$ reported antibiotics is the method to reduce it. Approximately one quarter $24.2 \%(n=102)$ didn't not know how sickle cell anemia is cured.

The majority of students $(71.4 \%)$ were aware about sickle cell disease is inherited blood disorder (Figure 1). Approximately two third $(64.1 \%)$ reported that Sickle Cell Disease diagnosis Via a blood test (Figure 2).

Table 3 shows participants dental knowledge of the sickle cell disease. Over half the participants did not ever treat patients with sickle cell anemia $57.7 \%(\mathrm{n}=244)$ or ask the patient for some investigation $53.7 \%(\mathrm{n}=227)$ or gives prophylactic antibiotic before extraction $52.4 \%(\mathrm{n}=221)$.

Approximately half $53.6 \%(\mathrm{n}=226)$ of students have information about oral manifestations of SCA and reported bleeding $52.8 \%$ ( $\mathrm{n}=223$ ) as a serious complication during dental procedures. The majority $75.1 \%(\mathrm{n}=316)$ think that patient's physician should be consulted about the patient's myocardial status and most of the participants $57.8 \%(\mathrm{n}=245)$ think that preventive dental care is important.

With regard to students' self-reported use of pain killer, they reported Paracetamol as best medication for SCA $(28.1 \% \mathrm{n}=118)$. About $(43.8 \%, \mathrm{n}=183)$ reported the main contraindication for dental treatment with the sickle cell anemia patients is any surgical procedure.

Around one third of the participants reported that hair-on-end appearance is the most radiographic feature appearance for sickle cell anemia patients (Figure 3). The distribution of the most common oral manifestation reported by the participants (Figure 4).

Chi square test showed a statistically significant association between knowledge questions and demographics $(\mathrm{p}<0.05)$.Females, 24-27 years, and level 12 participants were more likely to have a better knowledge (Table 4).

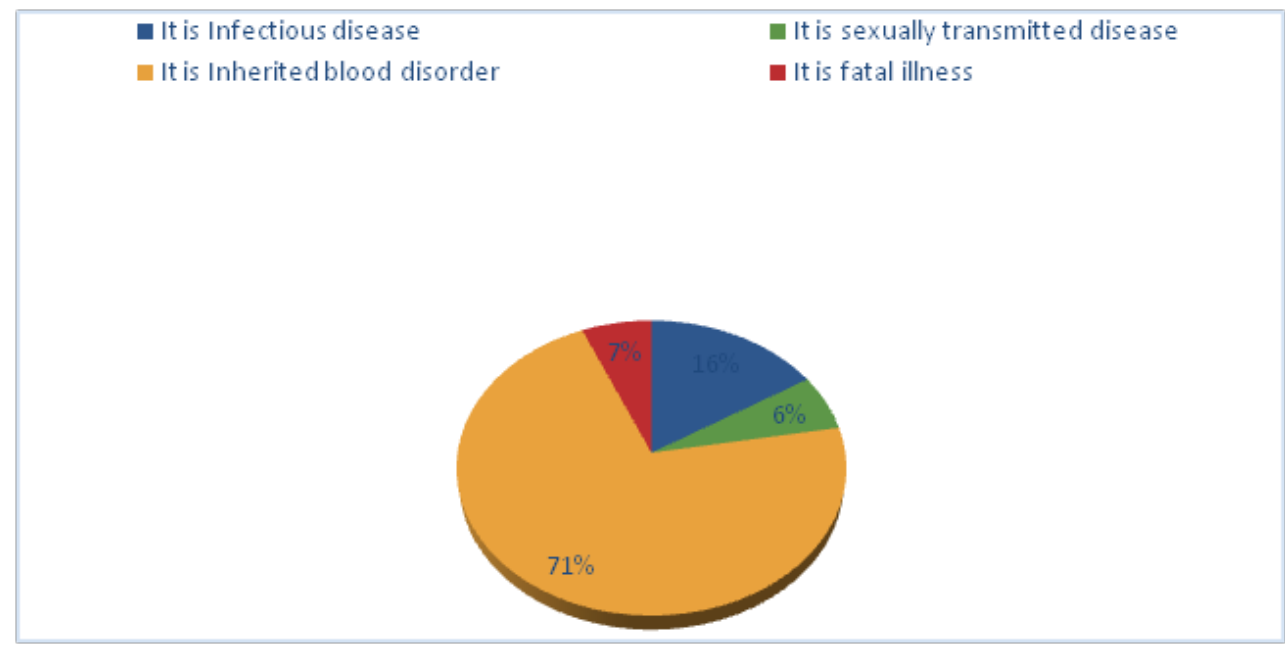

Figure I Response of the participants to how sickle cell disease is cause. 
Table 2 General knowledge of sickle cell disease

\begin{tabular}{|c|c|c|c|}
\hline & & $\begin{array}{l}\text { Frequency } \\
\text { (n) }\end{array}$ & $\begin{array}{l}\text { Percent } \\
\text { (\%) }\end{array}$ \\
\hline \multirow[t]{3}{*}{ What make sickle cell disease serious disease? } & Lead to death & 155 & 36.6 \\
\hline & Result in anemia & 237 & 55.9 \\
\hline & Others & 32 & 7.5 \\
\hline \multirow[t]{4}{*}{$\begin{array}{l}\text { When is the appropriate time to test for sickle cell } \\
\text { disease? }\end{array}$} & Newborn screening programs & 233 & 55 \\
\hline & Doctor check ups & 103 & 24.3 \\
\hline & At HIV testing & 49 & 11.6 \\
\hline & At sexually transmitted disease testing & 39 & 9.2 \\
\hline \multirow[t]{3}{*}{ What is the major role of hemoglobin in blood? } & The red pigments give a red color to blood & 115 & 27.2 \\
\hline & Binds with RBC to transport oxygen & 269 & 63.6 \\
\hline & As a defending mechanism & 39 & 9.2 \\
\hline \multirow[t]{3}{*}{$\begin{array}{l}\text { What do you think the protocol used for the patients } \\
\text { having sickle cell anemia? }\end{array}$} & Early morning & 231 & 55 \\
\hline & Late morning & 68 & 16.2 \\
\hline & I don't know & 121 & 28.8 \\
\hline \multirow[t]{2}{*}{$\begin{array}{l}\text { Is there an effective method that significantly reduces the } \\
\text { risk disease? }\end{array}$} & Yes & 226 & 53.6 \\
\hline & No & 196 & 46.4 \\
\hline \multirow[t]{3}{*}{ If yes, what is the methods to reduce this disease? } & Take insulin & 45 & 10.8 \\
\hline & Antibiotics & 186 & 44.6 \\
\hline & I don't know & 186 & 44.6 \\
\hline \multirow[t]{4}{*}{ How is sickle cell anemia been cured? } & Bone marrow transplant & 85 & 20.1 \\
\hline & Avoid marrying & 125 & 29.6 \\
\hline & Using drugs & 110 & 26.1 \\
\hline & I don't know & 102 & 24.2 \\
\hline
\end{tabular}

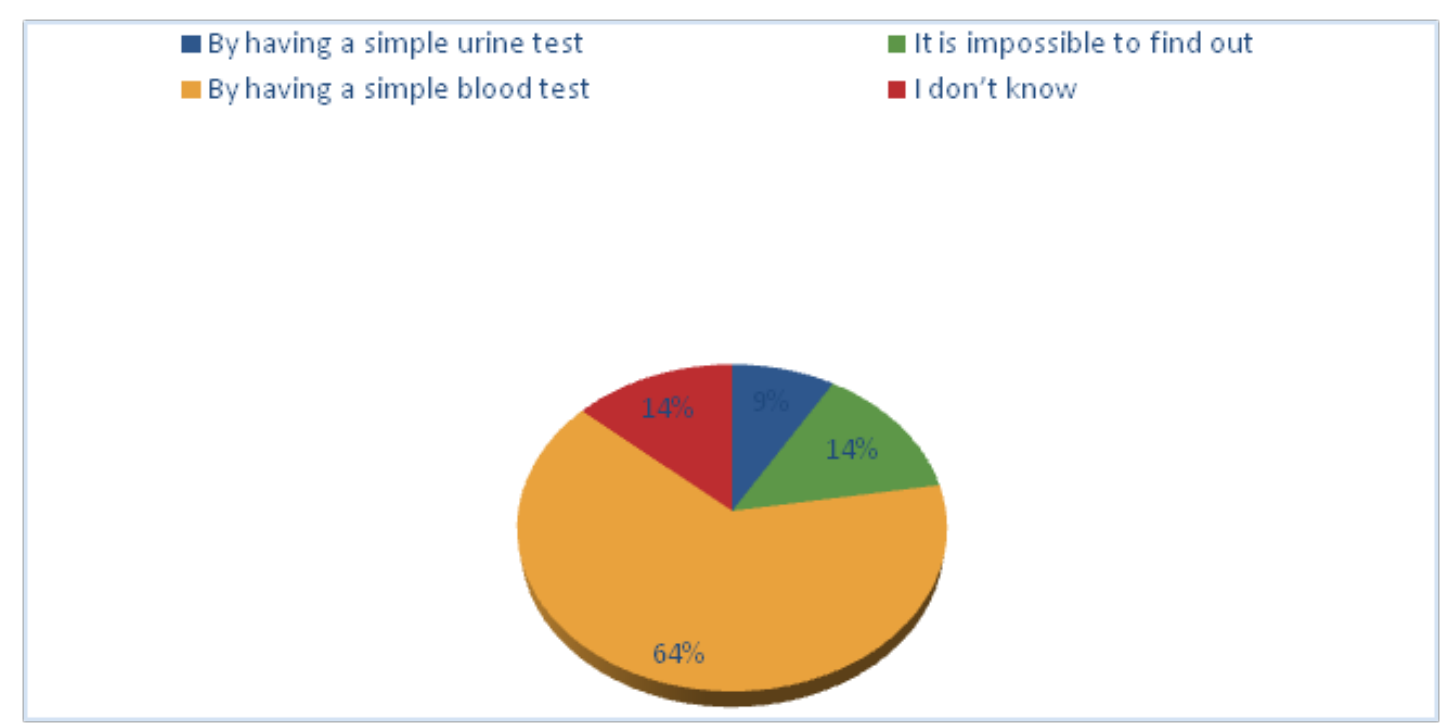

Figure 2 Response of the participants to diagnosis of sickle cell disease.

Citation: Meslet AAl, Hamedi HAl, Zhrani HAl, et al. Knowledge and awareness of sickle cell anemia among dental students in Riyadh Elm University. J Dent Health Oral Disord Ther. 2019;10(3):218-224. DOI: 10.15406/jdhodt.2019.10.00488 
Table 3 Dental knowledge of sickle cell disease

\begin{tabular}{|c|c|c|c|}
\hline & & Frequency & Percent \\
\hline & & (n) & (\%) \\
\hline \multirow[t]{2}{*}{ Have you ever treat patients with sickle cell anemia? } & Yes & 179 & 42.3 \\
\hline & No & 244 & 57.7 \\
\hline \multirow[t]{2}{*}{ Did you ask the patient for some investigation? } & Yes & 196 & 46.3 \\
\hline & No & 227 & 53.7 \\
\hline \multirow[t]{2}{*}{ Did you give prophylactic antibiotic before extraction? } & Yes & 201 & 47.6 \\
\hline & No & 221 & 52.4 \\
\hline \multirow{2}{*}{$\begin{array}{l}\text { Do you have any information about oral manifestations for sickle } \\
\text { cell anemia patients? }\end{array}$} & Yes & 226 & 53.6 \\
\hline & No & 196 & 46.4 \\
\hline \multirow[t]{4}{*}{ What is the type of pain killer used for sickle cell anemia patients? } & Paracetamol & 118 & 28.1 \\
\hline & Warfarin & 91 & 21.7 \\
\hline & Morphine & 97 & 23.1 \\
\hline & Ibuprofen & 114 & 27.1 \\
\hline \multirow[t]{4}{*}{$\begin{array}{l}\text { What the serious complication of sickle cell anemia patients during } \\
\text { dental procedures? }\end{array}$} & Tiredness & 47 & II.I \\
\hline & Bleeding & 223 & 52.8 \\
\hline & Difficulty breathing & 82 & 19.4 \\
\hline & I don't know & 70 & 16.6 \\
\hline \multirow[t]{3}{*}{ How you treat infection of patients with sickle cell anemia? } & Prophylactic penicillin & 128 & 30.5 \\
\hline & Pneumococcal vaccine & 125 & 29.8 \\
\hline & I don't know & 167 & 39.8 \\
\hline \multirow[t]{4}{*}{$\begin{array}{l}\text { The main contraindication for dental treatment with the sickle cell } \\
\text { anemia patient is? }\end{array}$} & Routine care during a crisis & 78 & 18.7 \\
\hline & LA & 71 & 17 \\
\hline & $\mathrm{RCT}$ & 86 & 20.6 \\
\hline & Any surgical procedure & 183 & 43.8 \\
\hline \multirow[t]{2}{*}{$\begin{array}{l}\text { Do you think that patient's physician should be consulted about } \\
\text { the patient's myocardial status? }\end{array}$} & Yes & 316 & 75.1 \\
\hline & No & 105 & 24.9 \\
\hline \multirow[t]{3}{*}{ Do you think that preventive dental care is important? } & Yes & 245 & 57.8 \\
\hline & Not necessary & 108 & 25.5 \\
\hline & Treat only Emergency & 7I & 16.7 \\
\hline
\end{tabular}


Table 4 Association between knowledge and demographic characteristics

\begin{tabular}{|c|c|c|c|}
\hline & \multicolumn{3}{|c|}{ p value } \\
\hline & Age & Gender & Level \\
\hline How does someone get sickle cell anemia? & 0.745 & 0.091 & $.000 *$ \\
\hline What make sickle cell disease serious disease? & $.006 *$ & $.025 *$ & 0.059 \\
\hline When is the appropriate time to test for sickle cell disease? & 0.335 & 0.616 & $.000 *$ \\
\hline What is the major role of hemoglobin in blood? & $.038 *$ & $.000 *$ & 0.054 \\
\hline Have you ever treat patients with sickle cell anemia? & 0.557 & $.000 *$ & 0.273 \\
\hline Did you ask the patient for some investigation? & 0.205 & $.000 *$ & 0.112 \\
\hline How can you know patients with sickle cell disease? & 0.092 & $.025 *$ & $.000 *$ \\
\hline What the most radiographic feature appearance for sickle cell anemia" patients? & 0.533 & 0.408 & $.001 *$ \\
\hline Did you give prophylactic antibiotic before extraction? & 0.547 & $.003 *$ & $.000 *$ \\
\hline Do you have any information about oral manifestations for sickle cell anemia patients? & 0.116 & $.040 *$ & $.002 *$ \\
\hline What the most common oral manifestations of this disease? & $.004 *$ & $.011 *$ & $.000 *$ \\
\hline What is the type of pain killer use for sickle cell anemia" patients? & 0.77 & 0.213 & 0.125 \\
\hline What the serious complication of sickle cell anemia" patients during dental procedures? & 0.291 & 0.08 & $.012 *$ \\
\hline What do you think the protocol use for the patients have sickle cell anemia? & 0.091 & $.002 *$ & $.005^{*}$ \\
\hline Is there an effective method that significantly reduces the risk disease? & 0.392 & $.050 *$ & $.001 *$ \\
\hline If yes what is the methods to reduce this disease? & 0.415 & $.055^{*}$ & 0.072 \\
\hline How you treat infection of patients with sickle cell anemia? & 0.085 & 0.076 & $.009 *$ \\
\hline How is sickle cell anemia been cured? & $.006 *$ & $.015^{*}$ & $.018^{*}$ \\
\hline The main contraindication for dental treatment with the SCA patient is? & 0.148 & $.000 *$ & $.000 *$ \\
\hline Do you think that patient's physician should be consulted about the patient's myocardial status? & 0.086 & 0.176 & $.045^{*}$ \\
\hline Do you think that preventive dental care is important? & 0.206 & 0.071 & $.000 *$ \\
\hline
\end{tabular}

*indicates statistical significance

\begin{tabular}{|c|c|c|c|c|}
\hline $0.0^{\circ}$ & $10.0 \%$ & $20.0 \%$ & $30.0 \%$ & $40.0 \%$ \\
\hline Enamel hypoplasia & & & & \\
\hline Multiple caries & & & & $34.4 \%$ \\
\hline Hypercementosis & & $19.2 \%$ & & \\
\hline I don't know & & & & $34.4 \%$ \\
\hline
\end{tabular}

Figure 3 Response on the most common radiographic feature for sickle cell anemia. 


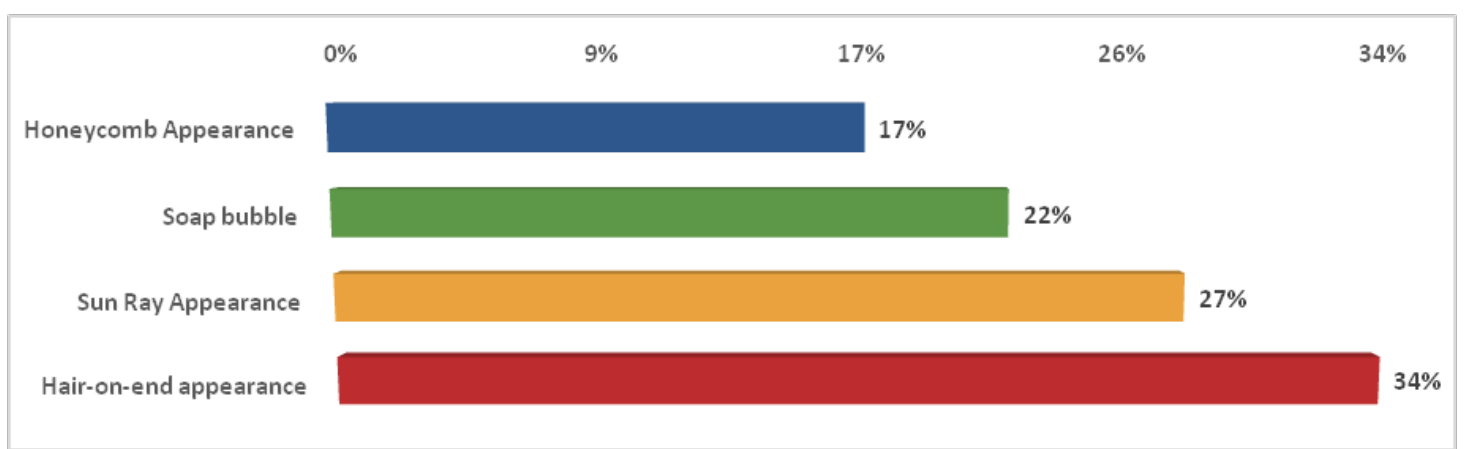

Figure 4 Response on the most common oral manifestation.

\section{Discussion}

Sickle cell disease has pathological effects in dental tissues and the oral cavity. Basic knowledge of sickle cell anemia among dentists and dental students before any dental procedure is mandatory so this study aimed to determine the knowledge of dental students related to Sickle Cell Anemia.

Descriptive analysis showed satisfactory knowledge about the complication related to SCA. Gomes et al., ${ }^{19}$ describes that the level of knowledge of primary health care workers in Brazil about sickle cell disease is low $(45.8 \%)$, while Isah et al. ${ }^{20}$ study the majority of respondents have high knowledge about sickle cell disease (97.6\%). Approximately 55\% of African American Students' Awareness of Sickle Cell Disease. ${ }^{21}$ Malay et al. ${ }^{18}$ reported that level of knowledge of first year dental students was found to be nearly $100 \%$. Silva et al,..22 reported the knowledge of sickle cell anemia, $44.0 \%$ of the students solved the questions and regards to odontological complications caused by sickle cell anemia only $30.4 \%$ marked the correct answer, the result of this study show less knowledge comparing to our study.

More than $50 \%$ were aware of the fact that bleeding was the most common related complication, which is reported by multiple studies. ${ }^{23,24}$ One of those investigations was carried out by, ${ }^{25}$ which showed a distinct relationship between SCA and problems linked with coagulation of blood leading to prolonged bleeding.

Regarding the diagnosis only $44 \%$ of students knew about the diagnosis of anemia and $22 \%$ of students answered correctly regarding treatment of anemia 18 . This could be a reason of these students being linked to theoretical courses instead of clinical exposure. Comparing these findings with our results suggest that the level of clinical students' knowledge in clinical criteria including the diagnosis and treatment part of anemia is superior.

Training programs should be conducted to make the dental students aware of anemia and the importance of precautionary measures to avoid any complications during dental procedure. In addition, raise the level of awareness by all possible ways among dental students as they could educate their patients in the future.

\section{Limitations of the study}

Naturally, there are some limitations to the general ability of these findings, because the present study was confined to Riyadh Elm University. Another limitation refers to the small sample size data collection.

\section{Conclusion}

The awareness of dental students toward the sickle cell anemia is a satisfactory level, but dental School should provide more courses and training about the policy of treat patient with SCA.

\section{Acknowledgments}

None.

\section{Conflict of interest}

The author declares that there is no conflict of interest.

\section{References}

1. Bodnar LM, Scanlon KS, Freedman DS, et al. High prevalence of postpartum anemia among low-income women in the United States. $\mathrm{Am}$ J Obstet Gynecol. 2001;185(2):438-443.

2. Benenson I, Porter S. Sickle Cell Disease: Bone, Joint, Muscle, and Motor Complications. Orthopaedic Nursing. 2018;37(4):221-227.

3. Piel FB, Steinberg MH, Rees DC. Sickle cell disease. New England Journal of Medicine. 2017;376(16):1561-1573.

4. Creary M, Williamson D, Kulkarni R. Sickle cell disease: current activities, public health implications, and future directions. $J$ Womens Health (Larchmt). 2007;16(5):575-582.

5. Makani J, Williams TN, Marsh K. Sickle cell disease in Africa: burden and research priorities. Ann Trop Med Parasitol. 2007;101(1):3-14.

6. Nasserullah Z, Alshammari A, Abbas MA, et al. Regional experience with newborn screening for sickle cell disease, other hemoglobinopathies and G6PD deficiency. Ann Saudi Med. 2003;23(6):354-357.

7. AlHamdan NA, AlMazrou YY, AlSwaidi FM. Premarital screening for thalassemia and sickle cell disease in Saudi Arabia. Genet Med. 2007;9(6):372-377.

8. National Heart, Blood and Lung Institute. Evidence- based management of sickle cell disease: Expert panel report. 2014.

9. National Heart, Blood and Lung Institute. Sickle cell disease. 2018.

10. National Human Genome Research Institute. Learning about sickle cell disease. 2016.

11. Natrajan K, Kutlar A. Disorders of hemoglobin structure: sickle cell anemia and related abnormalities. Williams Hematology. 2015.

12. Rouse LE, Hays GL. Dental considerations in sickle cell anemia. Gen Dent. 1979;27:18. 
13. Javed F, Correa FOB, Almas K, et al. Orofacial manifestations in patients with sickle cell disease. The American journal of the medical sciences. 2013;345(3):234-237.

14. Da Fonseca MA, Oueis HS, Casamassimo PS. Sickle cell anemia: a review for the pediatric dentist. Pediatric dentistry. 2007;29(2):159-169.

15. Kelleher M, Bishop K, Briggs P. Oral complications associated with sickle cell anemia: a review and case report. Oral Surgery, Oral Medicine, Oral Pathology, Oral Radiology, and Endodontology. 1996;82(2):225-228.

16. Kishore M, Panat SR, Aggarwal A, et al. Evidence based dental care: integrating clinical expertise with systematic research. J Clin Diagn Res. 2014;8(2):259-262.

17. Iqbal A, Glenny AM. General dental practitioners' knowledge of and attitudes towards evidence based practice. $\mathrm{Br}$ Dent $\mathrm{J}$. 2002;93(10):587-591.

18. Malay KK, Duraisamy R, Brundha MP. Awareness regarding anemia among 1 st year dental undergraduate students. Drug Invention Today. 2018;10(8).

19. Gomes LM, Vieira MM, Reis TC, et al. Knowledge of family health program practitioners in Brazil about sickle cell disease: a descriptive, cross-sectional study. BMC family practice. 2011;12(1):89.
20. Isah BA, Yahaya Musa UK, Ibrahim MTO, et al. Knowledge and Attitude Regarding Premarital Screening for Sickle Cell Disease among Students of State School of Nursing Sokoto. Annals of International Medical and Dental Research. 2016;2(3):29-34.

21. Ogamdi SO. African American students' awareness of sickle cell disease. Journal of American College Health. 1994;42(5):234-236.

22. Silva CAD, Santana CLD, Andrade RDC. Evaluation of dentistry students' knowledge on hematologic disorders. RGO-Revista Gaúcha de Odontologia. 2016;64(3):287-292.

23. Ballard HS. Hemostatic alterations in sickle cell anemia. In: Caughey WS, editor. Biochemical and clinical aspects of hemoglobin abnormalities. Academic Press, Cambridge. 1978:67-76

24. Mann JR. Ancrod in sickle-cell crisis. Lancet. 1975;1(7757):934-937.

25. Averett RD, Norton DG, Fan NK. Computational imaging analysis of fibrin matrices with the inclusion of erythrocytes from homozygous SS blood reveals agglomerated and amorphous structures. J Thromb Thrombolysis. 2017;43(1):43-51. 